\title{
EFFECTIVE WAYS CLOUD COMPUTING CAN CONTRIBUTE TO EDUCATION SUCCESS
}

\author{
BV Pranay kumar ${ }^{1}$, Sumitha kommareddy², N.Uma Rani ${ }^{3}$ \\ ${ }^{1}$ Department of information technology, CJITS, Jangaon, Warangal. \\ pranaybv4u@gmail.com \\ ${ }^{2}$ Department of information technology, CJITS, Jangaon, Warangal. \\ sumithareddyk@gmail.com \\ ${ }^{3}$ Department of computer science and engineering,CJITS, Jangaon, Warangal. \\ Nagavelli.umarani@gmail.com
}

\begin{abstract}
Cloud computing and education sounds ambiguous on the face of it. Naturally, it's because, very few individuals, publishers and users alike come from the education sector. In most cases, cloud computing is only associated with businesses and how they can leverage their efficiencies. Just to introduce how the cloud deserves a place in our current education institution, it's important to reiterate the education philosophy. Its essence is knowledge. It's this knowledge which brings advancement, achievement and success. However, there are several things which make these parameters unattainable. In blunt language, this is failure. Small classrooms, lack or resources, short-handed staff, lack of adequate teachers...the list is endless. One way or the other, cloud computing can be utilized to improve education standards and activities. The end result will be to curb the above problems and instead, boost performance.
\end{abstract}

\section{KEYWORDS}

Cloud Computing, Web service, Virtualization, Grid Computing, Virtual Computing Lab, Higher education institutions, Remote areas.

\section{INTRODUCTION}

Cloud computing has taken major chunk of attention from various communities in society like researches, student, business, consumer and government organization. As the human needs cropped and paved way for digitization of information a new buzzword GIG data evolved. Big data is the main source for coming of cloud computing in the show, everyday lots of data in the size of PETA bytes are uploaded in the digital world which required lots of storage and computing resources. Cloud Computing, also known as utility computing, delivering the service as software, platform and infrastructure as a service in pay-as-you-go model to consumers. It's just get anything for the pay model. Industry surveys says on this services as "Cloud computing, the long held dream of computing as a utility, has the potential to transform a large part of the IT industry, making software even more attractive as a service.

System of education has been gradually expanded, and the education object has slowly turned to social staff. Education has evolved from teacher centric to learner centric .Blooms taxonomy [11] ( multiple intelligence of learner ) of teaching can now is made easy with support of cloud computing where you get everything and now the teaching methodologies like chalk - black board, physical interaction took a new transition to online and is growing fast than ever. line tutor which helps has to take class in any hour is an advance of learning using technology. Elearning and online solution is what we required in education environment.

DOI : $10.5121 /$ acij.2013.4402 
With the advent of awareness and modernization of present society, quite a good number of people are receiving education, a series of new problems have emerged. For example: As teaching methods change, the existing teaching-learning methods cannot meet demand and need quite a good amount of infrastructure with high prices and with the constant expansion of education, the existing teaching facilities also need to constantly update. More importantly the present generation student desires to update the very fast changing world and want to be in pace with others of this global village. When Cloud Computing appears, it provides a new solution to establish a unified, open and flexible network teaching platform and reduce the hardware input .Internet is the resource where we can transform cloud computing, it can deliver the most advanced software and educational materials, hardware resources and services to students and educators in even the most impoverished or remote school districts in the state, without the need for advanced IT expertise at those locations. At the same point, it does more for significantly less, providing needed relief for currently strained education budgets [12]. IT companies are eager to encourage educational adoption of cloud computing; for example, Google Apps for Education Suite comprises Google Mail, Calendar, Talk, Docs, Sites and Video with zero cost and without advertisements [1], According to a Forrester cost analysis [9], Google Apps is more effective than a Microsoft Exchange e-mail. Based on CSU research, the costs of software licensing, server hardware and staffing to support 50,000 users by using Microsoft Exchange e-mail (the number of undergraduate e-mail accounts at CSU) would be $\$ 9,774,000$ per year [2]. The cost of Google Apps for businesses is $\$ 50$ per user per year, or with 50,000 users, $\$ 2,500,000$ per year. The cost of Google Apps Education Edition, however, is $\$ 0$ per year [2].

From the example above, the industrial cloud computing solution for the educational institution gave an estimated savings from about $\$ 9,774,000$ per year to $\$ 2,500,000$ per year in the ROI for "businesses version" or to zero cost of licensing and equipment in the "educational version". From the last two examples, we can see that both approaches, industrial (or commercial) and non-commercial cloud computing solutions can be successfully employed within educational institutions and another example, IBM launched IBM Cloud Academy that is provide a global forum for educators, researchers and IT professionals from education industry to pursue cloud computing initiatives, develop skill and share best practices for reducing operating costs while improving quality and access to education. In this way users do not need to buy a server, only need to purchase related "services" can create an efficient network teaching platform [10]. Using of cloud computing in academicians in universities are not aware of benefits and characteristic of minimizing the cost of cloud computing. From an IT-management view, it radically reduces resource management costs —including electric power, cooling and system management personnel, while driving up the utilization of servers and software licenses, which in turn reduces purchasing requirements [12].

\section{Benefits of Cloud Computing}

- High return on investment(ROI)

- Reduced implementation and maintenance costs

- Increased mobility for a global workforce

- Scalable and Flexible infrastructures

- Short time to market

- IT department transformation (focus on innovation vs. Maintenance and implementation)

- "Greening" of the data center

- Increased availability of high-performance applications to small/medium-sized businesses [3] 


\section{RELATED WORKS}

Internet has changed the present world and there is a drastic change in usage of a computer. people are addicted with computer from mail to online shopping. But now cloud has changed the complete meaning of internet. This powerful desktop application is available on internet and also in database which is available from anywhere anytime with any device. With this new invention we are getting lucky like E-Learning, Teacher student online projects [10], and many more.

\subsection{Improve economies of scale}

The main problem we get in the class room is students get feared asking questions or waste time of the lecture which can be solved virtually. Students can use online space and can attend the classes or do their projects by interacting with their guides. Teacher can create attention to all the students not showing interest only to crammed students. With this environment the workload can be reduced and can improve the ability of student .This can leverage on economies of scale outside the classroom.

\subsection{Improve rapport and ease assignments}

Many schools have already introduced computer and are also following many technologies. Many schools and colleges give assignment works during vacations. With the cloud computing students are able to interact, do the assignments as they are on single computer. This process not only is efficient but also saves time and improves the quality in students.

\subsection{Easy access to education resources and effective sharing}

Introduction of cloud has benefitted the colleges, institutes and schools. The idea behind this is students can share beyond their ideas. The main thing is colleges can spend less on new infrastructure, software, textbooks and improvise the quality of learning by providing all these virtually. This not only helps the management but also enables the students to get more knowledge which leads quality of education, development in academics. All these are great aspects .However the management has to plan for their investment for cloud.

\section{PURPOSE OF RESEARCH}

Students' learning is no longer confined within the classroom in the era of e-learning 2.0[11]. The environment of IT education could be improved to let student access learning resources anywhere. IGNOU (Indira Gandhi national Open University) is the good example of e-learning. The free software can be adopted for constructing the cloud computing service for the environment of IT like OpenOffice.org such as word processing, spreadsheets, and presentations. Only a browser is needed for students to connect to the cloud computing service for learning.

\subsection{Example1}

\section{ENGINEERING INSTITUTE-Computer Lab}

All the colleges have computer labs in which some are fully equipped but there are many colleges with deficiency of infrastructure, platform, and software's due to many problems which are not to be discussed. So in such situation cloud plays a important role where students from rural areas can get quality education through their virtual machines. 
Assume a college with 3 computer labs which are only connected with cloud using Paas(platform as a service)model. But students are connected to their tool virtually, execute their programs and can store them in a server. In worst case even if the system gets crashed due to some virus the programs are safely stored.

\subsection{Example2}

AICTE - Microsoft Cloud Adoption Project

All India Council for Technical Education (AICTE) has partnered with Microsoft Corporation India Pvt.Ltd.to implement Cloud email offering for all its institutes. As a part of Cloud Adoption all institutes get access to Microsoft Office 365 for Education.

O365 for Education, a no-cost suite of communication and collaboration tools includes the following:

Messaging Apps: Exchange online (10 GB inbox per student with 18MB attachment)and Outlook calendar 25 GB online storage space (through Windows Sky Drive) Office web apps - Online companions to Microsoft Word, Excel and PowerPoint and OneNote 24/7 online support for students and administrators .

\section{APPLICATIONS OF CLOUD IN EDUCATION}

Educational cloud computing services represent a growing variety of useful services available on the internet, and the most innovative and rapidly developing element of technology and education. It also promises to provide multiple services that will be very useful to the students, faculty and staff [11].The role of cloud computing in university education should not be underestimated, as it can provide important gains in offering direct access to a wide range of different academic resources, research applications and educational tools [12].

Educational cloud computing is quickly taking the education community by storm as more platforms, applications and services are being developed for academic cloud computing.

Some students and researches are already using a type of cloud computing-based application and services. Furthermore, these applications are heavily investing in cloud computing as being the future of the academic cloud computing [13]. Some of these applications are Microsoft, Google, IBM, HP, Amazon, Sales force, Amanda and Zamanda. A. Amazon Education Cloud Computing To assist educators in providing cloud computing instruction ,Amazon Web Services (AWS) offer teaching grants supporting free usage of AWS for students in eligible courses. The grants will provide educators with free usage for each student en rolled in courses with AWS as part of the curriculum. Furthermore, AWS provide a highly scalable cloud computing platform for schools and universities which encompasses high availability, dependability, and the flexibility to enable the faculty, students and researchers to build a wide range of applications. With AWS, students and others can requisition compute power, storage, and other services gaining access toa suite of elastic IT infrastructure services for educational purposes. Moreover, AWS can be characterized as Iaas. This means that Amazon provides basic computing capability a virtual machine container, high performance networking reliable and redundant storage, in a remote location $[19,20,21$, 22].The AWS provides some educational services for the students and faculty: _ Research grants for academic researchers using AWS in their work_ Access to the available resources27_ Tutorial and project grants for the student organizations using AWS for self-directed learning_ Teaching Grants for faculty based on AWS_ Efficiency and cost-effectiveness in the institution's IT 
Infrastructure As a result, the deployment and reliability for the educational infrastructure are basically managed by AWS as shown in Figure 4 [40, 41, 22]

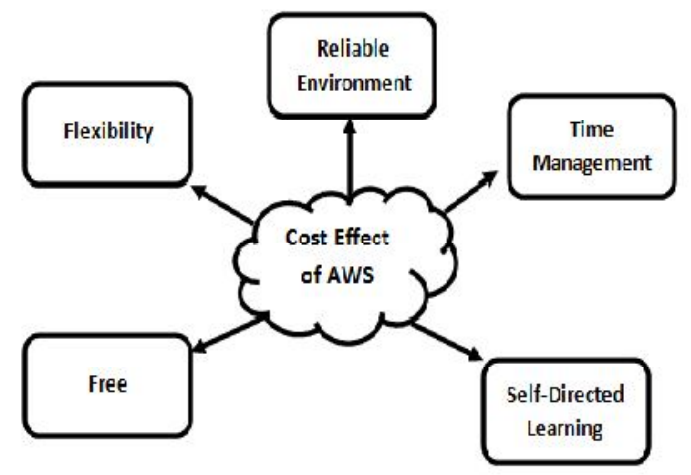

Fig. 4. Cost effect of AWS

\section{A) Amazon Cloud Services in Education: Amazon Web}

Services represent the most extensive cloud service to date that provides resizable compute capacity in the cloud. It is designed to make web scale computing easier for developers.

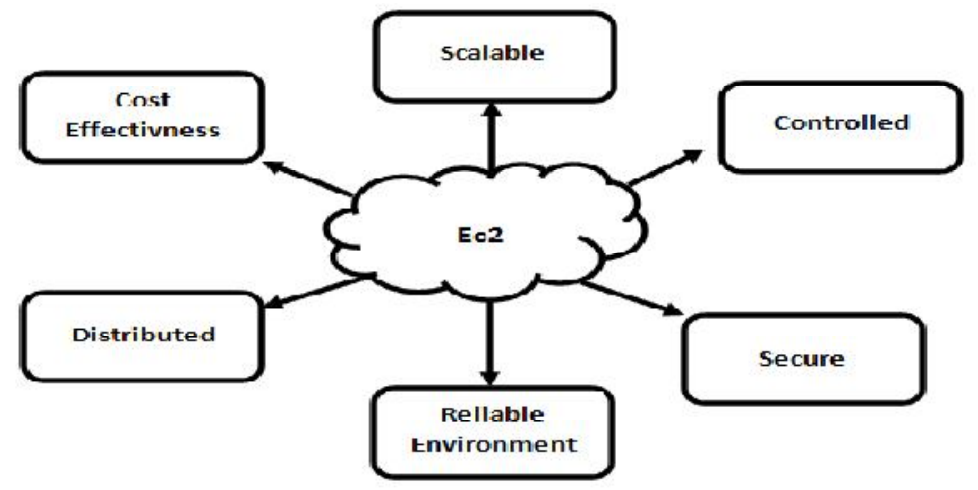

Fig. 5. Amazon EC2 Services

Amazon offers many cloud services, including:_ Amazon Elastic Compute Cloud (Amazon EC2): A web service that offers virtual machine and extra CPU cycles for the institutional organization. Figure 5 presents the services of Amazon EC2 [39, 54, 42]_ Amazon Simple Storage Service (Amazon S3): Allows the students, faculty and researchers to store items with a limited size in Amazon's Virtual storage_Amazon Simple Queue Service (SQS): Offers different kinds of messages passing API, so that educators can talk to each other_Amazon SimpleDB: A web service for running queries on a structured data set in the cloud in real time_ Amazon Virtual Computing Laboratory (Amazon VCL): A free source implementation of a secure production level on-demand utility computing for accessing a wide-area of computational resources, storage and software. Figure 6 illustrates the implementation of VCL [53]. 


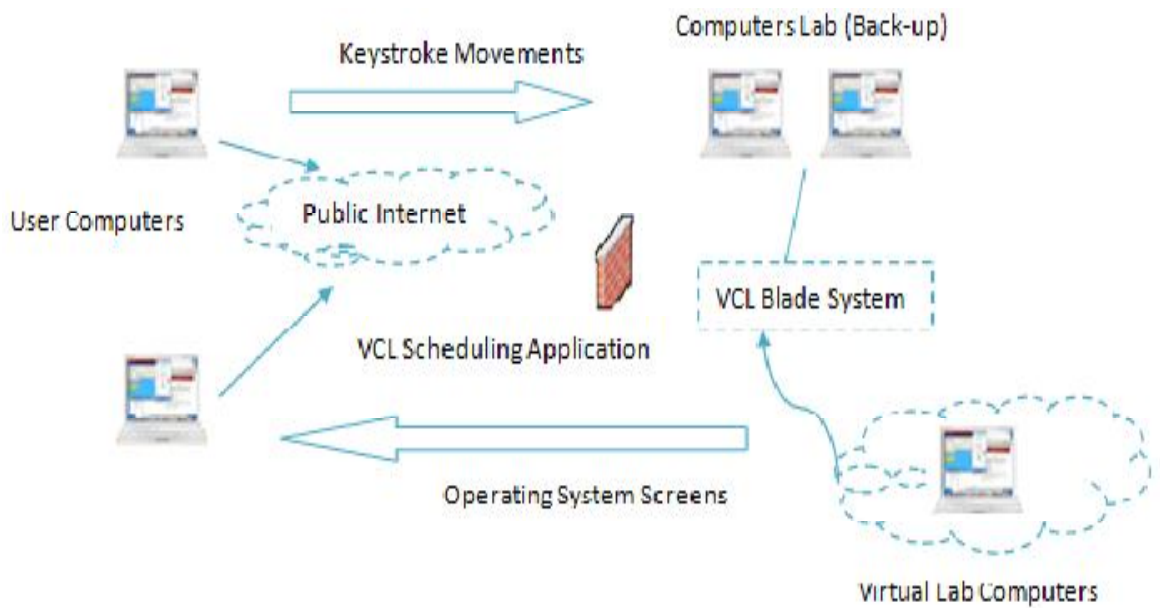

Fig. 6. Implementation of VCL

\section{B. Microsoft Education Cloud Computing}

The Microsoft software and services strategy are about the power of choice a hybrid model of resources that enables the students and researcher to transfer to the cloud. It also lets the researchers to arise workloads across the infrastructures and complement their actual IT assets with Web-based services. Microsoft cloud services give students and researchers the ability to make full use of the same Microsoft technologies in the educational institution $[1,32]$. Additionally, all services offer greater financial flexibility to educational institutions and enable lower costs to develop, scale, operate and migrate the systems that are distributed between the cloud and the data center. Microsoft Live@edu can serve a range of needs as shown in Figure 7.

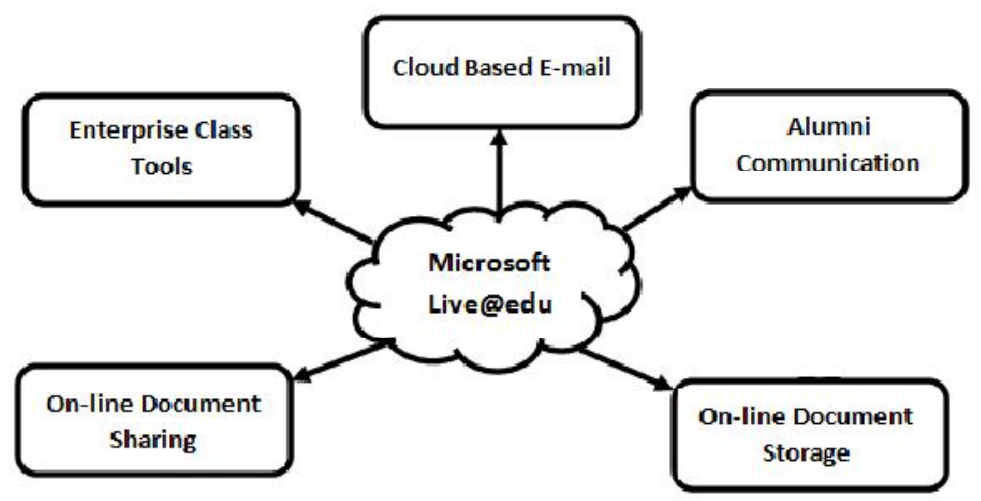

Fig. 7. Features of Microsoft Live@edu

Microsoft Live@edu is usable through popular web browsers for various types of operating systems. It is available at no cost, and it helps IT departments [2, 36]: Reduce the costs for IT infrastructure, such as maintenance _ Minimize time spent maintaining e-mail systems and on strategic initiatives _ Provide flexibility and collaboration with peers and faculty _ Reduce the time evaluating risk and help make informed decisions about the use of educational cloud computing_ Improve high student expectations, including anywhere access to the latest technology 28 _ Free on demand resources_ Test and deploy large-scales applications in different environment, Create applications that can be shared by many students simultaneously. 


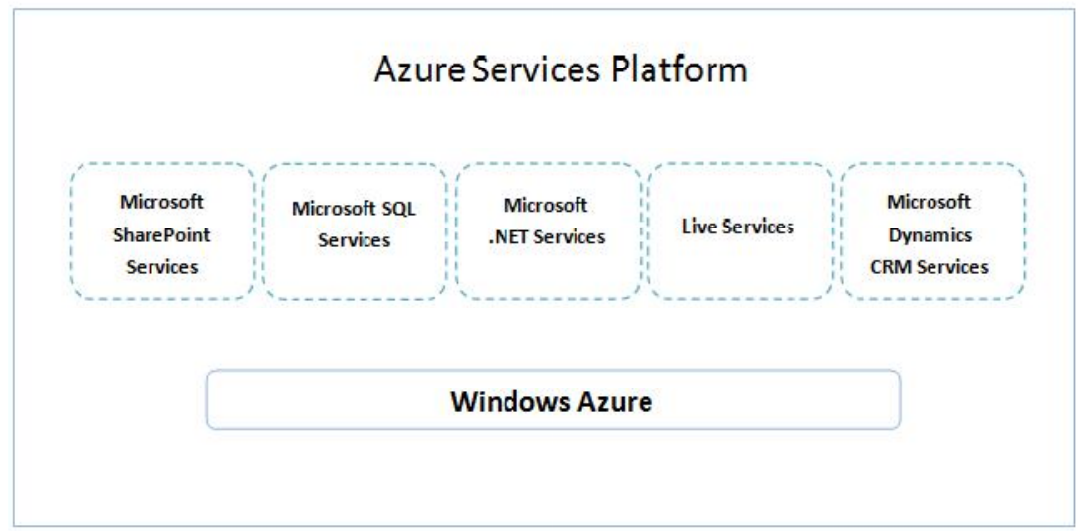

Fig. 8. Azure Services Platform

The solution of Microsoft's cloud computing is also called Windows Azure, an operating system that allows the universities and colleges to run operating system applications and stores data by Microsoft server. Furthermore, the Azure Services Platform (ASP),includes services that allow the faculty,students and researchers to establish user identities, manage work flows, execute other functions such as Microsoft's online computing platform [37] as shown in Figure 8 [54]. ASP consists of different keys illustrated in Figure 9

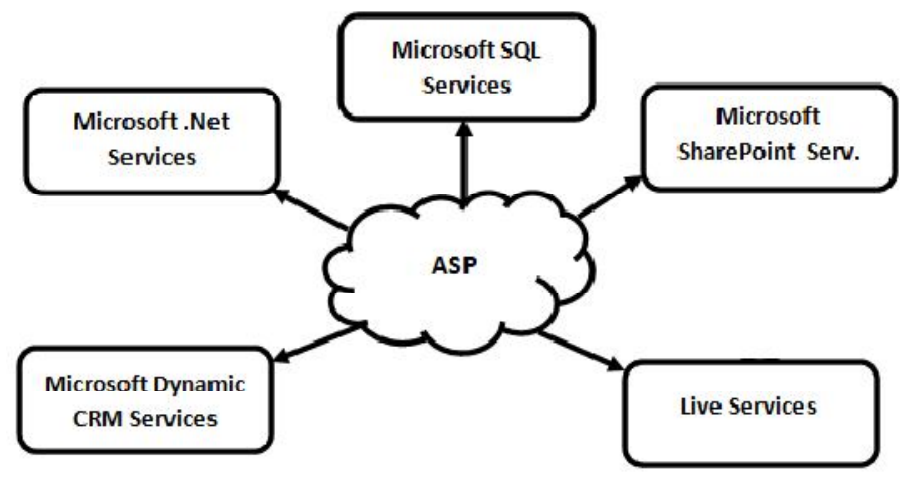

Fig. 9. Key components of ASP

\section{Google Applications for Educational Cloud Computing}

Google App Education (GAE) as a new generation of cloud computing-based Web application development platform, enables its users such as the faculty, researchers and students and so on, to operate Web applications within the Google Infrastructure.GAE is available at no cost to institutions, universities and education community [16]. The teachers, students, and staff can share ideas more rapidly and get things done more adequately they have got an efficient communication and sharing tools. Google Apps Education Edition lets technical administrators provide a collection of Web-based messaging tools such as Google Mail, Google Talk, Google Sites , Google Video and Google Calendar to the faculty, students and staff for free in addition to productivity and collaboration tools such as Google Docs Package [17].

1) Google Applications For Educational Cloud Computing: GAE provides a range of online tools and services that give secure communication and collaboration capabilities to the institutional schools and let the faculty, researchers and students choose the solutions that suit their unique needs. 


\begin{tabular}{|l|l|}
\hline Service & \multicolumn{1}{|c|}{ Service details } \\
\hline Support & Phone support \\
\hline Application & 3rd party applications \\
\hline Video & Google Video \\
\hline Cost 3 & Google Video \\
\hline Scheduling & Resource scheduling \\
\hline Storage Enough Space & Enough Space \\
\hline Users & No limit \\
\hline
\end{tabular}

Table I: GAE Services

2) Google Calendar: Google Calendar is a published, shared, integrated and accessible calendar for scheduling courses. Moreover, the faculty, researchers and students can use the Google calendar to manage their business and organize their work groups.

3) Google Sites: Google Calendar enables the faculty, researchers and students to build, create and publish information with Google tools.

4) Google Video: Google Video allows the faculty, researchers and students to share information using secure and private video tools.

5) Google Talk: Google Talk is an Instant Messaging (IM) tool of Google. Colleagues can communicate remotely with limited conservation by IM.

6) Google Mail: Google Mail uses labels and filters to help students, faculty and researchers organize their email, manage the flow of incoming messages and get mail from other email accounts in their Gmail inbox in addition to sending messages from different addresses.

7) Google Docs: It is considered the main task tool of the course, because it allows participants to collaborate synchronously in the same document.

\section{IBM Cloud Services to Education}

IBM offers a new set of cloud services to deliver programs, computer lab contents and services to the faculty, students and researchers at schools, colleges and universities, without the need for advanced IT expertise at those locations. The IBM SmartCloud for Education is a set of cloud services and offerings designed to help education systems leverage predictive analytic to get realtime insights on educators and institutional performance, enhance researcher effectiveness, and alleviate constrained lab resources for learning [10, 24,25, 46]. By using the IBM SmartCloud for Education services, schools and higher education institutions can address the significant challenges they face: student achievement, graduation rates, scholarship funding, and demands for IT resources for research, so that educators can also benefit from selfservice reservation of, and seamless access to virtual computer resources both on campus and on the IBM public cloud as show in Figure 10 [56]. 


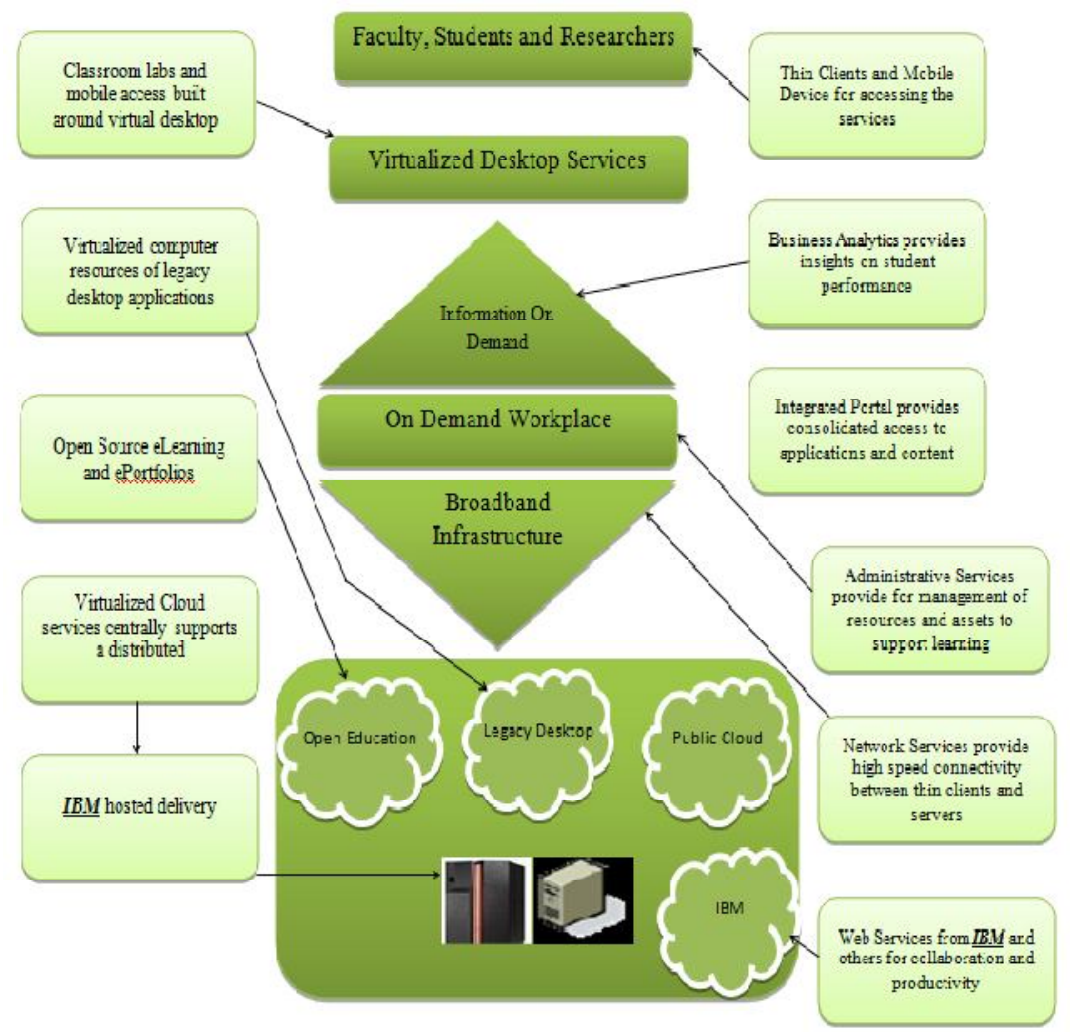

Fig. 10. IBM Cloud Computing Components for Education

1) IBM Cloud Computing Services in Education: Educational institutions, universities and schools face constant demands from the students, staff, faculty and researchers for stable, quick and security rich access to labs and computing resources. However, setting up and maintaining the IT environment for this purpose can affect several challenges such as high costs and lack of scalability to perform fluctuating demand and quality of service challenges despite budget constraints. Cloud computing can assist in addressing these challenges and provide cost-effective access to the resources required to meet the needs $[26,9,10]$. IBM Virtual Computing Lab (VCL) Solutions for Cloud, part of the IBM Smart Cloud for Education, can support open/free source software and a technical infrastructure that serve the needs of educational institutions. IBM's solutions for VCL include:_ Ready-to-use communication and collaboration tools that connect the students, faculty and administrative staff for learning outside the campus _ IBM Tivoli Provisioning Manager to manage images and provisioning with VCL _ IBM Global Business Services (GBS) VCL fast and secure Services to assist plan, implement and support emigration to a VCL-based cloud_ IBM Smart Cloud services and resources for VCL private cloud users are available $[26,46]$.

\section{E. Salesforce.com Cloud Computing In Education}

Salesforce is a trusted leader in cloud computing and customer relationship management, as well as a respected pioneer in the educational institutes. As part of these philanthropic efforts, the Salesforce.com Foundation makes its products available at the educational institutes at a big discount. Salesforce is being used by higher institutions of all sizes and across all sectors to: a) Work more efficiently, b) Deepen engagement with constituents, c) Measure and share impact and success d) Work more collaboratively, e) Deliver programs and services in innovative new 
ways. Higher education institutions are using the Salesforce.com cloud computing platform for its instant scalability, ease of configuration, and support for multiple functional roles.

1) Key Features Of The Salesforce.com Cloud Computing In Education: The salesforce.com can help the students, researchers and faculty manage their tasks more efficiently to provide different features as shown in Figure $11[47,48]$. The key features of the salesforce.com in education are: a) App. Development, b) Team Collaboration, c) Real Time Analysis, d) Mobile Applications, e) Recruitment and Marketing, f) Advancement, g) Student Record Management, h) Student Tracking.

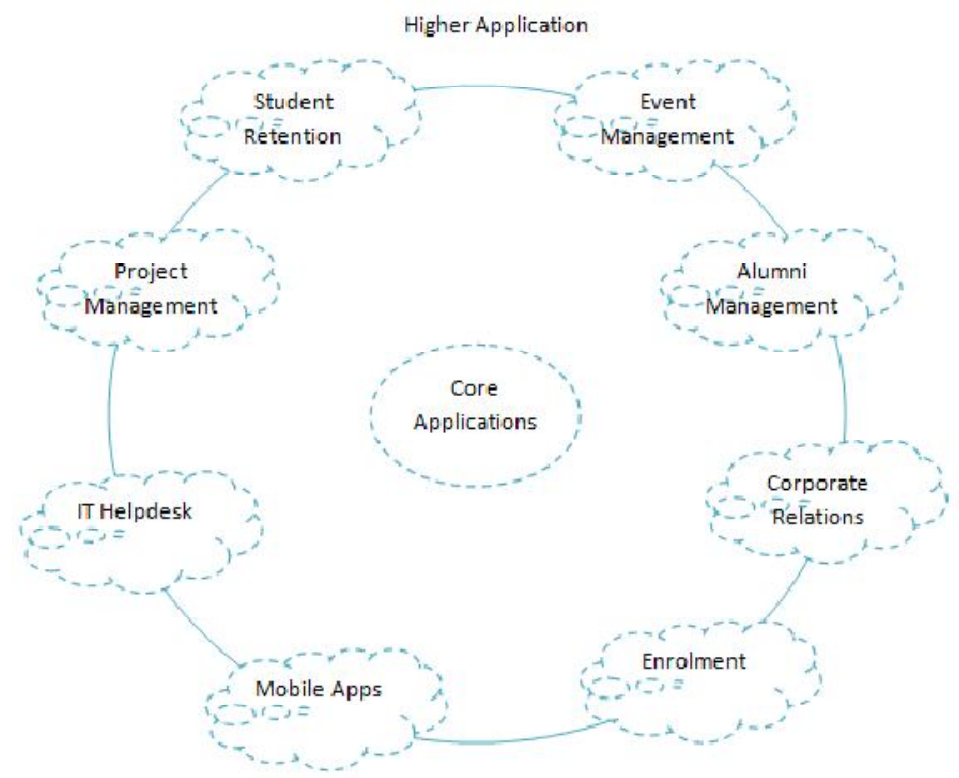

Fig. 11. Salesforce.com cloud computing in education

\section{F. HP Cloud Computing In Education}

With integrated support and service tools, HP gets the students, faculty and researchers to the cloud and ensures they get the most from the cloud once the educators are there. Services from HP can transform the IT infrastructure and optimize several clouds. HP Cloud computing in education is a way to build, operate, and consume IT that makes educational resources such as the student records, knowledge management, faculty collaboration and etc. available on demand. HP Cloud Computing delivers a comprehensive, integrated cloud solution on one platform, with all the services so prized by service providers in the institutions, and IT professionals [28].

1) HP Cloud Computing in Education: HP Cloud Computing Curriculum and HP Cloud System courses from HP Education Services help the educators address their cloud needs. With award winning on-line or face-to-face courses from HP Education Services, the students, faculty and researchers can combine mission critical computing with HP \& heterogeneous management of their existing environment with HP Software. The characteristics of a cloud system in HP are as following: a) True Integration, b) Complete management and automation, c) Security, d) Scalability.

2) Cloud Map Of HP Education For Cloud Computing: HP Cloud System is the product of HP's experience in delivering application management, and Converged Infrastructure capabilities. It enables the educational institutions to build and manage cloud services across private, public 
clouds, and traditional IT environments without having to know about HP Cloud System's infrastructure. The core of HP Cloud in education is illustrated in Figure 12 [28].

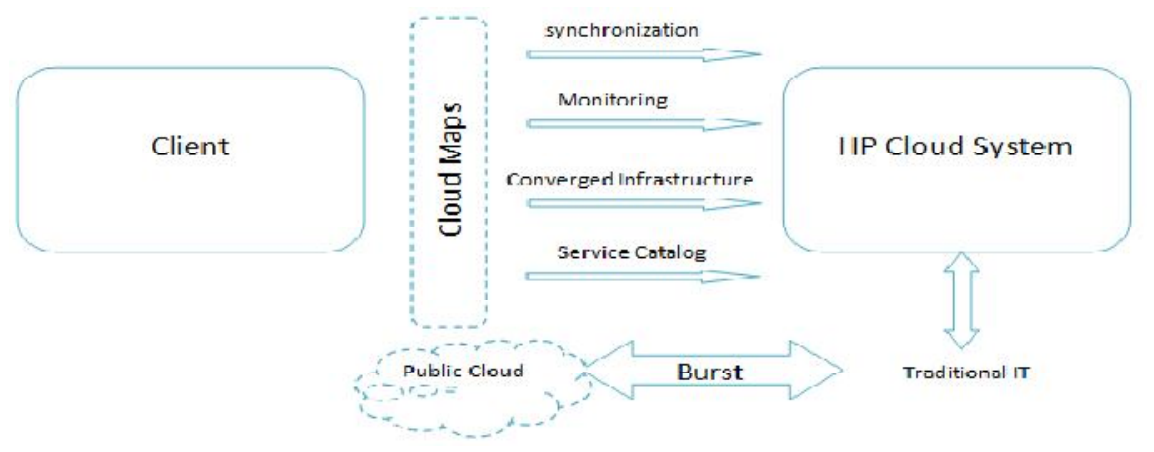

Fig. 12. The Core Cloud System in HP

\section{G. AMANDA And ZMANDA Cloud Computing For Education}

Amanda Enterprise was built to address these challenges providing a backup and added functionality tat support fast installation, simplified management, enterprise-class functionality, and low-cost subscription fees. As an open source backup and archiving software, Amanda Enterprise only uses standard formats and tools, thus effectively freeing the students from being locked into a vendor to retrieve the data [29]. Zmanda Cloud Computing is a radically simple-touse and cost-effective backup and disaster recovery solution. Backup and recovery solutions have been focused to several products such as Amanda Enterprise, Zmanda Recovery Manager for MySQL and Zmanda Internet Backup to the educational organizations [30].

\section{RISKS OF CLOUD COMPUTING IN EDUCATION}

There are clearly some major potential benefits to institutions deploying cloud services however; it challenges computing service personnel who may fear the consequences of their roles being outsourced. The universities and schools should consider the challenges and risks prior to transferring to the cloud $[32,45]$. Examples of these risks are:

Cloud Service Failure: Insufficiency of financing and immature markets could guide some cloud providers out of business and any loss or deterioration of service delivery performance, as well as a loss of investment, make the universities and schools to the risk of having to perform their own duties and obligations, thus being exposed to contractual or legal liability to their employees, third parties, the students or even the public.

Compliance Regulations: Due to the increasing number of regulations and need for operational transparency, the educational institutions are increasingly adopting consolidated and consistent sets of compliance controls

Data Privacy: The multi-tenancy, reuse of hardware and software profiles, and resiliency due to the redundant nature of cloud means a greater risk of incomplete or unlock deletion or denial of service attacks on institutions' confidential data.

Assurance to Service Provider: This proposes a dependency on a particular cloud service provider for service preparation, especially when data portability is not supported. 


\section{COMPARING THE CLOUD COMPUTING APPLICATIONS}

The computing industry analysts have made some expectations on how Cloud computing will change the entire computing industry. Cloud computing is expected to increase market, business and productivity applications opportunities. As the computing industry switches to providing $\mathrm{PaaS}$ and SaaS for consumers in academic institutions and enterprises to on-demand access, allowing IT to limit idea-to-innovation barriers and timelines to develop overall productivity and collaboration, by providing whatever capabilities are needed, whenever and wherever required. Recently, several academic and industrial organizations have started investigating and developing technologies and infrastructures for Cloud Computing.

In this section, we compared some of the educational cloud computing tools such as Amanda Network Backup, Google App Engine, Amazon EC2, HP, Microsoft Windows Azure, IBM and SalesForce in the Table II, based on some of the key parameters driving a Cloud Computing platform. In order to grasp the differences between these applications, it is essential to classify the basics of educational cloud computing applications based on the Platforms supported, Languages Supported, Monitoring and Support Services [55].

Where CI: Control Interface; GNA: Guaranteed Network Availability; COS: Compatible Operating Systems; PLS: Programming Languages Supported; FSF: Free Security Features.

\begin{tabular}{|c|c|c|c|c|c|c|c|}
\hline $\begin{array}{l}\text { Specificati } \\
\text { ons }\end{array}$ & $\begin{array}{c}\text { AMANDA } \\
\text { NETWOR } \\
\text { K } \\
\text { BACKUP }\end{array}$ & $\begin{array}{c}\text { GOOG } \\
\text { LE } \\
\text { APP } \\
\text { ENGI } \\
\text { NE }\end{array}$ & $\begin{array}{c}\text { AMAZON } \\
\text { EC2 }\end{array}$ & HP & $\begin{array}{c}\text { MICRO } \\
\text { SOFT } \\
\text { WINDO } \\
\text { WS } \\
\text { AZURE }\end{array}$ & IBM & $\begin{array}{c}\text { SALESFO } \\
\text { RCE }\end{array}$ \\
\hline CI & - & $\begin{array}{l}\text { API } \\
\text { Standar } \\
\text { d }\end{array}$ & $\begin{array}{c}\text { API } \\
\text { Standard } \\
\text { Command } \\
\text { Line }\end{array}$ & $\begin{array}{l}\text { API Standard } \\
\text { Command } \\
\text { Line }\end{array}$ & $\begin{array}{c}\text { API } \\
\text { Standard } \\
\text { Comman } \\
\text { d Line }\end{array}$ & $\begin{array}{c}\text { API } \\
\text { Standard } \\
\text { Application/ } \\
\text { Control } \\
\text { Panel }\end{array}$ & $\begin{array}{c}\text { API } \\
\text { Standard } \\
\text { Web Based } \\
\text { Application } \\
\text { /Control } \\
\text { Panel } \\
\end{array}$ \\
\hline COS & $\begin{array}{c}\text { Mac } \\
\text { Linux/Unix } \\
\text { Windows }\end{array}$ & $\begin{array}{l}\text { Linux } \\
\text { Windo } \\
\text { ws } \\
\text { Server } \\
2008\end{array}$ & $\begin{array}{c}\text { Open } \\
\text { Solaris } \\
\text { Oracle } \\
\text { Enterprise } \\
\text { Red Hat } \\
\text { Enterprise } \\
\text { Ubuntu } \\
\text { Linux } \\
\text { Windows } \\
\text { Server }\end{array}$ & $\begin{array}{c}\text { Windows } \\
\text { Server } 2003 \\
\text { Cent OS } \\
\text { Windows } \\
\text { Server } 2008\end{array}$ & $\begin{array}{c}\text { Windows } \\
\text { Server } \\
2003 \\
\text { Windows } \\
\text { Server } \\
2008\end{array}$ & $\begin{array}{c}\text { Enterprise } \\
\text { Linux } \\
\text { openSUSE } \\
\text { Linux } \\
\text { SUSE Linux } \\
\text { Red Hat }\end{array}$ & Linux \\
\hline PLS & & $\begin{array}{c}\text { Python } \\
\text { JAVA }\end{array}$ & $\begin{array}{c}\text { PHP } \\
\text { JAVA } \\
\text { Python } \\
\text { WinDev }\end{array}$ & $\begin{array}{l}\text { SAS } \\
\text { SQL } \\
\text { Ruby } \\
\text { Java }\end{array}$ & $\begin{array}{c}\text { Advance } \\
\text { d } \\
\text { Firewall } \\
\text { Critical } \\
\text { Data } \\
\text { Privacy } \\
\text { Secure } \\
\text { Permissio } \\
\text { ns } \\
\text { Persisten } \\
\text { cy } \\
\end{array}$ & $\begin{array}{l}\text { root access } \\
\text { to the } \\
\text { servers }\end{array}$ & $\begin{array}{l}\text { Ruby } \\
\text { JAVA } \\
\text { PHP }\end{array}$ \\
\hline $\begin{array}{c}\text { Free } \\
\text { Support }\end{array}$ & No & Yes & No & Yes & No & Yes & \\
\hline FSF & & $\begin{array}{c}\text { Persiste } \\
\text { ncy }\end{array}$ & $\begin{array}{c}\text { Advanced } \\
\text { Firewall }\end{array}$ & & $\begin{array}{c}\text { Advance } \\
\text { d }\end{array}$ & $\begin{array}{c}\text { Snapshot } \\
\text { Backup }\end{array}$ & $\begin{array}{c}\text { Permissions } \\
\text { Data }\end{array}$ \\
\hline
\end{tabular}


Advanced Computing: An International Journal (ACIJ ), Vol.4, No.4, July 2013

\begin{tabular}{|c|c|c|c|c|c|c|c|}
\hline & & & $\begin{array}{c}\text { Critical } \\
\text { Data } \\
\text { Privacy } \\
\text { Custom/Se } \\
\text { cure } \\
\text { Permission } \\
\text { s } \\
\text { Data } \\
\text { Protection }\end{array}$ & & $\begin{array}{c}\text { Firewall } \\
\text { Critical } \\
\text { Data } \\
\text { Privacy } \\
\text { Custom/S } \\
\text { ecure } \\
\text { Permissio } \\
\text { ns } \\
\text { Data } \\
\text { Protectio } \\
\text { n }\end{array}$ & $\begin{array}{c}\text { Critical Data } \\
\text { Privacy }\end{array}$ & $\begin{array}{c}\text { Protection } \\
\text { Fail over } \\
\text { Features } \\
\text { Backup } \\
\text { Storage } \\
\text { Persistency }\end{array}$ \\
\hline $\begin{array}{c}\text { Monitorin } \\
\mathrm{g}\end{array}$ & & & Yes.free & Yes.free & & $\begin{array}{c}\text { Yes, with a } \\
\text { Charge }\end{array}$ & Yes, Free \\
\hline $\begin{array}{c}\text { Auto } \\
\text { Scaling }\end{array}$ & & $\begin{array}{l}\text { Yes, } \\
\text { Free }\end{array}$ & Yes, free & No & & & Yes, Free \\
\hline Processor & & & $\begin{array}{l}\text { 32-bit } \\
\text { 64-bit }\end{array}$ & $\begin{array}{l}\text { 32-bit } \\
\text { 64-bit }\end{array}$ & & $\begin{array}{l}\text { 32-bit } \\
\text { 64-bit }\end{array}$ & \\
\hline $\begin{array}{c}\text { Load } \\
\text { Balancing }\end{array}$ & & $\begin{array}{l}\text { Yes, } \\
\text { Free }\end{array}$ & $\begin{array}{l}\text { Yes, with a } \\
\text { Charge }\end{array}$ & Yes, Free & & & Yes Free \\
\hline $\begin{array}{c}\text { Year } \\
\text { Founded }\end{array}$ & & 2008 & 2002 & 2005 & 2010 & & 1999 \\
\hline $\begin{array}{l}\text { Support } \\
\text { Service }\end{array}$ & $\begin{array}{l}\text { Phone } \\
\text { White } \\
\text { Papers } \\
\text { Blog \& } \\
\text { FAQ } \\
\text { Request } \\
\text { Form }\end{array}$ & $\begin{array}{l}\text { On-line } \\
\text { Resour } \\
\quad \text { ces } \\
\text { Forums }\end{array}$ & $\begin{array}{c}24 / 7 \\
\text { Forums and } \\
\text { Phone } \\
\text { On-line } \\
\text { Guides and } \\
\text { Resources }\end{array}$ & 24/7 Forums & $\begin{array}{c}24 / 7 \\
\text { Forums } \\
\text { and } \\
\text { Phone } \\
\text { On-line } \\
\text { Guides } \\
\text { and } \\
\text { Resource } \\
\text { s }\end{array}$ & $\begin{array}{l}\text { Diagnostic } \\
\text { Tools } \\
\text { Forums } \\
\text { Phone } \\
\text { On-line } \\
\text { Resources }\end{array}$ & $\begin{array}{c}\text { Knowledge } \\
\text { Base } \\
\text { On-line } \\
\text { Resources } \\
\text { Phone }\end{array}$ \\
\hline $\begin{array}{c}\text { Support } \\
\text { Web page }\end{array}$ & $\begin{array}{l}\text { http://zman } \\
\text { da.com/ }\end{array}$ & & $\begin{array}{l}\text { http://aws.a } \\
\text { mazon.com } \\
/\end{array}$ & $\begin{array}{l}\text { http://welcom } \\
\text { e.hp.com/ }\end{array}$ & $\begin{array}{c}\text { http://mic } \\
\text { rosoft.co } \\
\mathrm{m} /\end{array}$ & $\begin{array}{l}\text { http://www- } \\
\text { 935.ibm.com } \\
/\end{array}$ & $\begin{array}{c}\text { http://salesf } \\
\text { orce.com/ }\end{array}$ \\
\hline
\end{tabular}

Table II: Characteristics of listed companies based on specification.

\section{RELATED WORKS}

There are currently many different cloud computing platforms for education in use. C. Justin et al. [1] has proposed Seattle, which is educational networking, a free, portable, and lightweight platform using donated cloud computing. Seattle allows students to learn the concepts of networking and distributed systems on computers spread through the Internet. Seattle can also emulate cloud computing, peer-to-peer computing and classify computing within a simple area. S. Al Noor et al. [4] has proposed an architecture of cloud computing for education based on the availability of widespread resources to all around Bangladesh. This architecture can simply give an effective and flexible way to match the resources with the current economic condition through the utilization of unused resources and abstraction of third party involvements, as well as providing a more flexible environment so that the client can now configure his own security policy. N. Sultan [17] has demonstrated how institutions and universities are already taking advantage of the benefits of cloud computing, not only in terms of cost, but also efficiency and the environment. Moreover, educational establishments are likely to embrace cloud computing as many of them are bound to suffer from under-funding as a result of the global economic crisis. 


\section{CONCLUSION}

The Present problem of our country reaching technology to remote schools and educational institutes in imparting "equal and quality education to all" can be solved with mere small gadgets like ipad's, iphones, tabs thereby saving on purchase of computing infrastructure, licensing and purchase of software's and support personnel. In the era of "Big data" cloud computing has immense role in improving quality and enormous educational content available for students and research scholars. The success and high return on investment (ROI) of cloud infrastructure vests in the hands of bigger organizations and the public sector in particular. The success of cloud computing in education can be attributed to the acceptance of cloud computing by everyone in the field of education with good chunk of support by government.

This paper presents educational cloud computing and how the universities and institutions are already taking advantage of it, not only in terms of cost but also efficiency security, reliability and portability. Several general examples of cloud computing in education such as Microsoft, Google App, IBM, Amazon and others were provided and a case study of the applications was presented and explored in more details [54].

\section{CONTRIBUTION TO RESEARCH}

The area of cloud computing in education is still at a nascent stage. Existing research focuses particularly on the analytical aspects of the cloud computing applications, describing some current and accomplished educational and research products. The successful applications of cloud computing models at educational institutions have been evaluated only to a limited degree. In this respect, this paper takes a first step by systematically bringing together the various definitions of cloud computing in the education with the different ways to implement cloud computing. As a major result, this paper elaborates the simplified structure of service and applications of educational cloud computing, such as the characteristics of the educational platform and flexibility for all universities, schools and educational institutions. In addition, this paper presents different educational applications for education infrastructures implemented for using in academic section. The cloud computing in education will resolve not only from an academic point of view, but also particularly on a reduction of cost, effective communication, security, privacy, providing flexibility and accessibility.

\section{ACKNOWLEDGEMENT}

The authors would like to acknowledge the reviewers for their valuable comments, which contributed to the clarity of the paper and in particular for their suggestions for the statements of applications. We also thank Rev fr.Y.Papireddy, Director of Christu Jyothi Institute Of Technology Sciences for motivating and encouraging doing our Research work successful.

\section{REFERENCES}

[1] C. Justin, B. Ivan, K. Arvind and A. Tom, Seattle: A Platform for Educational Cloud Computing, SIGCSE09, March 37, 2009, Chattanooga, Tennessee, USA, 2009.

[2] P. Shanthi Bala, INTENSIFICATION OF EDUCATIONAL CLOUD COMPUTING AND CRISIS OF DATA SECURITY IN PUBLIC CLOUDS, (IJCSE) International Journal on Computer Science and Engineering Vol.02, No. 03, 2010, 741-745. 2007.

[3] M. Armbrust, et al, Above the clouds: A Berkeley view of Cloud Computing, UC Berkeley EECS, 2009. 
[4] S. Al Noor, G. Mustafa, S. Chowdhury, Z. Hossain, and F. Jaigirdar, A Proposed Architecture of Cloud Computing for Education System in Bangladesh and the Impact on Current Education System, (IJCSNS) International Journal of Computer Science and Network Security, VOL.10 No.10. 2010.

[5] M. Luis, R. Luis, C. Juan and L. Maik, A Break in the Clouds: Towards a Cloud Definition, ACM SIGCOMM Computer Communication Review, Volume 39, Number 1. 2005.

[6] Cloud Computing Articles. Cloud Computing Education, http://www.code2cloud.com/cloudcomputing-education/

[7] Cloud Computing Articles, SaaS+PaaS+IaaS. Free Cloud Apps for Educational Institutes: Schools, Colleges, Universities, http://www.technopulse. com/2010/08/free-cloud-apps-educationalinstitutes.html/

[8] IBM Academic Initiative. Cloud computing: Delivering Internetbased information and technology services in real time, https://www.ibm.com/developerworks/university/cloud/

[9] IBM Sales and Distribution - Solution Brief for Education. IBM Cloud Academy Education for a smarter planet, ftp://dispsd-40-www3.boulder.ibm.com/

[10] R. CJB and N. Evans. A PROPOSAL FOR THE ADOPTION AND USE OF CLOUD COMPUTING IN SECONDARY EDUCATION IN SOUTH AFRICA, 11th DIS Annual Conference 2010, 2nd 3rd September,Richardsbay, University of Zululand, South Africa, 2010.

[11] THE ABC'S OF ENGINEERING EDUCATION: ABET, BLOOM'S TAXONOMY, COOPERATIVE LEARNING, AND SO ON

[12] K. Youry and V. Volodymyr. Cloud Computing Infrastructure Prototype for University Education and Research, WCCCE '10, May 78, 2010, Kelowna, Canad, 2010.

[13] M. Grimes, T. Jaeger and J. Lin. Weathering the Storm: The Policy Implications of Cloud Computing, iConference, 2009.

[14] Microsoft Education Cloud Computing. The most comprehensive solutions for the cloud. On earth, http://www.microsoft.com/en-us/cloud/

[15] Microsoft in Education - IT solutions. Microsoft Live@edu, http://www.microsoft.com/education/en-us/solutions/Pages/liveedu.aspx/

[16] R. Elumalai and V. Ramachandran. A Cloud Model for Educational e-Content Sharing, European Journal of Scientific Research, ISSN 1450-216X Vol.59 No.2, pp.200-207. 2011.

[17] N. Sultan. Cloud computing for education: A new dawn?, International Journal of Information Management, 109116, 302010.

[18] M. Victoria, and D. Brbara. Cloud computing for education: A new dawn?, A design of a postgraduate course on Google Apps based on an Institutional Personal Learning Environment (iPLE).

[19] Amazon Web Services. Overview of Amazon Web Services, http :==media:amazonwebservices:com=AWSOverview:pdf=

[20] X. Dong and L. Hui. Reviewing some Cloud Computing Platforms, ISBN 978-952-5726-09-1, Proceedings of the Second International Symposium on Networking and Network Security (ISNNS 10), Jinggangshan, P. R., pp. 161-164, China. 2010.

[21] An Amazon Web Services Case Study. Migrating Applications to the Cloud, http://www.cloudcomputingcourse.com/

[22] Amazon Web Services. AWS in Education, http://aws.amazon.com/education/

[23] MC Graw Hill. Cloud Computing Basics, Chapter 1.

[24] IBM. New IBM Cloud Services to Address Education Challenges, http://www03.ibm.com/press/us/en/pressrelease/34642.wss/

[25] IBM Global Technology Services, Getting cloud computing right, http://www05.ibm.com/de/cloud/pdf/Gettingcloudcomputingright.pdf/

[26] IBM Sales and Distribution, Education, Solution Brief. IBM Virtual Computing Lab Solutions for Cloud, Solution Brief.

[27] salesforce foundation. salesforce for Higher Education, http://www.salesforcefoundation.org/product/

[28] HP CLOUDSYSTEM. A single platform for private, public, and hybrid clouds. Simply the most complete cloud system for enterprises and service providers, Hewlett-Packard Development Company. 2011.

[29] Amanda \& Zmanda. Amanda and Zmanda Applications, http://www.zmanda.com/

[30] Zmanda Cloud Backup. Zmanda Cloud Backup for Windows, http://www.zmanda.com/cloudbackup.html/

[31] Cloud Computing. Risk of Cloud Computing in Universities, http : ==www:istf:jucc:edu:hk=newsletter=IT03=IT $\square$ 3CloudComputing:pdf=[32] Microsoft, Education all 
Advanced Computing: An International Journal (ACIJ ), Vol.4, No.4, July 2013

in. Cloud Computing from Microsoft - Empowering Education through Choice, https://partner.microsoft.com/NZ/40142863/

[33] P. Thomas. Cloud Computing: A potential paradigm for practicing the scholarship of teaching and learning, Centre for Academic Development, University of Botswana.

[34] Microsoft, Cloud Computing Web Site. Cloud Computing in Education, http://www.edutechhosting.co.uk/

[35] A Microsoft U.S. Education white paper. Cloud computing in education Savings, flexibility, and choice for IT, http://www.microsoft.com/educloud/

[36] V. Toby, V. Anthony and E. Robert. Cloud Computing, A Practical Approach, ISBN-13: 978-0-07162694-1, 353 Pages. 2009.

[37] R. Herrick. Google This! Using Google Apps for Collaboration and Productivity, SIGUCCS09, October 1114, 2009, St. Louis, Missouri, USA. 2009.

[38] GOOGLE APPS EDUCATION EDITION. Google Apps Education Edition: communication, collaboration, and security in the cloud, http://www.google.com/a/edu/

[39] A. Vouk. Cloud Computing Issues, Research and Implementations, Journal of Computing and Information Technology - CIT 16, 2008, 4, 235246, doi:10.2498/cit.1001391. 2008.

[40] Amazon Web Services (AWS) Web Site. What is AWS - A comprehensive cloud computing platform, http://aws.amazon.com/what-is-aws/

[41] Amazon Web Services, Case Study. Application Hosting, http://aws.amazon.com/solutions/casestudies/

[42] Amazon Web Services (AWS), EC2 Web Site. Amazon Elastic Compute Cloud (Amazon EC2), http://aws.amazon.com/ec2/

[43] AWS Case Study: Educations.com, Web Site. AWS Case Study: Educations. com, http://aws.amazon.com/solutions/case-studies/educationscom/

[44] D. Jiabin. Virtualization, Application Streaming and Private Cloud Computing in a Training Laboratory, JOURNAL OF SOFTWARE, VOL. 5, NO. 11,doi:10.4304/jsw.5.11.1306-1313. 2010.

[45] N. Sclater. CLOUD COMPUTING IN EDUCATION: POLICY BRIEF, UNESCO Institute for Information Technologies in Education. 2010.

[46] Cloud-onomics in education, IBM Cloud Academy, Web Site. Cloud 9: Future Compatible Computing in Education, http://www.ibm.com/ibm/files/T641866T23726I58/EBE03001USEN.PDF/

[47] Silanis e-SignLive Services. Software-as-a-Service (SaaS) e-Signature Service, http://www.eignlive.com/services.html/

[48] Salesforce.com foundation, Higher Education Solution. Taking higher education to a higher level, http://www.salesforcefoundation.org/products/discounts/higher-ed/

[49] Salesforce:com foundation, Higher Education. The Real Time Cloud for Higher Education, http://www.salesforcefoundation.org/

[50] Cloud Computing Applications Web Site. Cloud Computing Applications and Services in Education, http://www.shaswatpatel.com/

[51] Microsoft News Center. Windows Azure and the Azure Services Platform: Making Microsofts Software-plus-Services Vision a Reality, http://www.microsoft.com/presspass/features/2008/oct08/10-27pdcfeature1.mspx/

[52] Computing Edge. Analyzing the Differences between Cloud Computingand Virtualization, http://computinged.com/insights/

[53] VCL Web Site. VCL Conceptual Overview Diagram, https://cwiki.apache.org/VCL/

[54] Understanding Cloud Computing in Education - Web Site. VCL Conceptual Overview Diagram, http://kasunpanorama.blogspot.com/2010/07/understanding-cloudcomputing- feel-easy.html/

[55] T. Harris. Cloud Computing Services - A comparison, http://www.thbs.com/

[56] IBM Cloud Academy. Education for a Smarter Planet:Cloud Computing in Education, http://www.cetpa-k12.org/ 